\section{The effect of nature of science activities on 4.th grade students' scientific process skills $^{1}$}

\section{Bilimin doğası etkinliklerinin ilkokul 4. sınıf öğrencilerinin bilimsel süreç becerilerine etkisi}

\section{Ü. Gülözge Türköz ${ }^{2}$}

Özet

Bilimsel süreç becerileri, bilimin temelidir ve araştırma yapmayı ve sonuç çıkarmayı sağlar. Bilimsel süreç becerileri, kişinin etrafındaki dünya hakkında bilgiler üretmesi ve düzenlemesi için belki de en önemli araçlardan biridir. Bu yüzden, öğrencilerin, bilimsel araştırma yapmak için gerekli anlayışa ve becerilere sahip olmaları gereklidir. Buradan hareketle bu çalışmanın amac1 Bilimin doğası etkinliklerinin ilkokul 4. Sınıf öğrencilerinin bilimsel süreç becerilerine etkisini incelemek olarak belirlenmiştir. $\mathrm{Bu}$ çalışma kapsamında deneme modeli türlerinden deneme öncesi, tek grup ön ölçüm-son ölçüm modeli kullanılmıştır. Denizli ili merkezinde bulunan orta sosyo-ekonomik düzeydeki ilkokullardan birinde, 2012-2013 eğitim-öğretim y1lında öğrenim gören 4. sinıf öğrencileri kapsamında (65 öğrenci) uygulamalar yapılmıştır. Çalıssma kapsamında veri toplama aracı olarak "Bilimsel Süreç Becerileri”" testi kullanılmıştır. $\mathrm{Bu}$ testin 4. Sınıf öğrencilerinin bilimsel süreç becerilerini ölçmek amaciyla seçilmesinin temel nedenlerinden birisi alan yazında Fen Bilimleri dersi kapsamında geliştirilmiş ve yayınlanmış en yeni test olmasıdır. Çalışma sonucunda bilimin doğasına yönelik etkinliklerle öğrenim gören

\footnotetext{
1 This study is a product of the project " Bilimin doğası etkinliklerinin öğrencilerin bilimsel süreç becerilerine, kavramsal anlamalarına ve bilimin doğası anlayışlarına etkisi ", which was carried out with the support of the Scientific Research Projects Unit of Pamukkale University (project number: 2013EĞBE006).

2 Ph.D., Pamukkale University, Faculty of Education, Department of Elementary Education, ggulel@pau.edu.tr
} 
Türköz, Ü. G. (2020). Bilimin doğası etkinliklerinin ilkokul 4. sınıf öğrencilerinin bilimsel süreç becerilerine etkisi. Journal of Human Sciences, 17(2), 558-571. doi:10.14687/jhs.v17i2.3834

Keywords: Scientific process skills, elementary çalışma grubu öğrencilerinin bilimsel süreç school, science education, nature of science. becerileri ölçeği son-ölçümden aldıkları (Extended English summary is at the end of puanların ortalaması, ön-ölçümde aldin ortalamasından yüksek çımıştır. this document)

Anahtar Kelimeler: Bilimsel süreç becerileri, ilkokul, fen eğitimi, bilimin doğası.

\section{Giriş}

Bilimsel süreç becerileri aktif düşünme sürecinde; bireylerin problemi fark etmeleri, çözümler üretmeleri, karar vermeleri ve öğrenmelerinde kullandıkları temel becerileri içermektedir. Genel olarak bu beceriler bilim insanlarının araştırma sürecinde problem çözmek için kullandıkları düşünme becerileridir (Taşdemir, 2013, s. 195).

Laçin Şimşek’e (2010) göre bilimsel süreç becerileri, bilimin temelidir ve araştırma yapmayı ve sonuç çıkarmayı sağlar. Bilimsel süreç becerileri, kişinin etrafindaki dünya hakkında bilgiler üretmesi ve düzenlemesi için belki de en önemli araçlardan biridir. Bu yüzden, öğrencilerin, bilimsel araştırma yapmak için gerekli anlayışa ve becerilere sahip olmaları gereklidir (NRC, 1996). Bir başka deyişle bilimsel süreç becerileri bilim öğrenmenin ve yapmanın ayrılmaz bir parçasıdır. Ayrıca bilimsel süreç becerileri sadece bilimle ilgili bazı içerik ve alanlarda değil, bilimi anlayarak öğrenmede ve bilimin tüm içeriklerinde her zaman kullanılır (Harlen, 1999, s. 129-130).

İlköğretim seviyesindeki çocuklar, bilim insanlarının araştırmalarında kullandıkları yola benzer bir yol ile kendi problemlerini oluşturup araştırırken bilimsel süreç becerilerini kullanilırlar. Soru sorar, ölçüm yapar, veri toplar, topladığı verileri yorumlar, eldeki verilere göre çıkarımlarda bulunurlar (Taşdemir, 2013, s. 193).

Bilimsel süreç becerileri temel süreç becerileri ve üst düzey süreç becerileri olarak başlıca iki grupta incelenmektedir. Temel süreç becerileri; gözlem, karşılaştırma, sınıflandırma, bilimsel iletişim kurma, ölçüm yapma, tahminde bulunma ve çıkarım yapma süreçlerinden oluşurken, üst düzey süreç becerileri ise; değişkenleri belirleme ve kontrol etme, hipotez kurma ve test etme, deney tasarlama ve yapma, işlevsel tanımlama, verileri yorumlama ve model kurmayı içermektedir (Martin, 2001, s. 32; Padilla, 1990; Bağc1- Kıllı̧, 2006; Yurt, 2013, s. 14). Temel süreç becerilerinin kazanımı okul öncesi ve ilköğretimin ilk yıllarında gerçekleşirken üst düzey süreç becerilerinin kazanımı ise ilköğretimin üst sinıflarında gerçekleşir (Yurt, 2013, s. 14).

Fen eğitiminin temel amaçlarından olan neden sonuç ilişkisi kurabilen ve kendi başına doğru karar alabilen bireyler yetiştirebilmek için, bilginin yapılandırma süreci bilimsel bilgiye ulaşma şeklini almıştır (MEB, 2013). Bu da ancak bilimsel yöntem hakkında bilgi verilmesi bilimsel süreç becerilerinin kullanımı ile sağlanabilir. Bu nedenle fen eğitiminin amaçlarından biri de bilimsel bilginin oluşum sürecinde nasıl yapılandırıldığını ve neler üzerine kurulduğunu incelemek olmalıdır(Driver, 1995). Dünyaya bilim insanlarının bakış açısıyla bakabilmenin yolu ise bilimin doğasını anlamaktır.

Bilimin doğasını bilimsel sorgulamadan, bilimin süreçlerinden ve bilimsel etkinlik sonucu üretilen bilgi birikiminden ayırt etmek ve bilimin ve bilimsel bilginin özelliklerine dikkat çekmek için belli başlı bazı konular vurgulanmışlardır (Abd-El-Khalick, Bell ve Lederman,1998). Bunlar: Bilimsel bilgi değişebilir; bilimsel bilgi özneldir ve kurama bağlıdır; bilimsel bilgi deneyseldir; bilimsel bilgi üretildiği sosyal ve kültürel ortamdan etkilenir; bilimsel bilgi yaratıc1lğga ve hayal gücüne bağlıdır; Bilimde gözlem ve çıkarımlar birbirinden farklıdır; bilimde yasalar ve kuramlar birbirinden farklıdır (Schwartz ve Lederman, 2002). Alan yazında ifade edilen liste tipi algilanan bu özellikler, fen eğitimi araştırmacılarının, bilim insanlarının, bilim felsefecilerinin üzerinde bilimin doğası hakkında uzlaşılmış görüş olarak adlandırılır (Ünal-Çoban, 2015). 


\section{Şekil 1. Bilimin Doğası Tanımı: Disiplinlerin Kesişimidir.}

Lederman'a (1992, 2007) göre bilimin doğası, bilimin epistemolojisini, bilimin bir öğrenme yolu olduğunu veya bilimsel bilginin gelişiminin doğasında var olan değerler ve inanışları ifade eder (Akt. Abd-El-Khalick ve diğ., 1998; Lederman, Abd-El-Khalick, Bell ve Schwartz, 2002; Yalçınoğlu ve Anagün, 2012). Bilimin doğasının anlaşılmasının amacı ile bilimin anlaşılmasının amaçları hemen hemen aynıdır. Bilim anlayışı bilimin içeriğinin bazı yönlerini anlama, sorgulama için bilimsel yaklaşım ve sosyal bir girişim olarak bilim anlayışı kazanılmasını kapsarken bilimin doğası da aynı konuları kapsar aynı zamanda bilim okuryazarlığı da bilimin doğasının ayrılmaz bir parçasıdır. Driver ve diğ.'ne (1996) göre bilimsel okuryazarlığı geliştirmek, arttırmak, ortak bir bilimsel anlayış ortaya çıkarmak ve bilimsel okuryazarlık oluşturmak bilimin ve bilimin doğasının anlaşılmasının ve öğrenilmesinin amaçlarındandır.

Bilinçli ve düzenli yöntemler kullanarak gündelik bilginin sınırlarını aşan iki bilgi türü bilimsel ve felsefi bilgidir (Çilingir, 2013:3). Bilimi anlamak, günümüz bilim çalışmalarından, bilimden önceki veya bilim dışı düşünme biçimlerini bilmemizi gerektirir (Doğan, Çakııoğlu, Bilican ve Çavuş, 2012: 1). Buradan hareketle "Bilim nedir? Nereden gelmiştir?" gibi sorulara verilecek cevapları bilim tarihinden öğrenmek mümkündür denilebilir. Cevizci $(2013,244)$ bilim felsefesini bilimin doğasına ve özellikle de yöntemlerine, kavramlarına, ön kabullerine ve bu arada, bilimin entellektüel disiplinlerin genel şeması içindeki yerine ilişkin araştırmalardan meydana gelen felsefi disiplin olarak tanımlamaktadır.

\section{Amaç}

Alan yazında yeni paradigma olarak bilimin doğasının ne olduğu üzerinde uzlaşılmış görüşlerden ziyade, uzlaşılamayan noktalardan yola çıkılarak bilimin doğasının daha iyi anlaşılacağı düşünülmektedir (Irzık ve Nola, 2011, Erduran 2014). Matthews (2012) ise; bilimin doğas1 listesindeki maddelerin öğretimsel ortamda öğretmenler ve öğrenciler açısından anlam ifade etmesi için felsefi ve tarihsel bağlamda zenginleştirilmesi gerektiğini belirtmiştir. Bu anlamda bakıldığı zaman fen programları içerik olarak farklılık gösterse de amaçlar bilimi bir bilme yolu olarak görme konusunda görüş birliği içindedirler. Öğrencilerin bilimi bilme yolu olarak kullanabilmesi için sorgulamaya dayalı ögrenme ortamlarında bilimsel süreç becerilerine sahip olmaları gerekir (Abd-ElKhalick, 2012).

Bu bağlamda bu çalışmanın amacı Bilimin doğası etkinliklerinin ilkokul 4. Sınıf öğrencilerinin bilimsel süreç becerilerine etkisini incelemek olarak belirlenmiştir.

\subsection{Araştırma Deseni}

\section{Yöntem}

Araştırma deseni olarak seçilen deneme modeli, neden sonuç ilişkilerini belirlemeye çalışmak amacı ile doğrudan araştırmacının kontrolü altında, gözlenmek istenen verilerin üretildiği araştırma modelidir (Karasar, 2000, s. 77). Bu çalışma kapsamında deneme modeli türlerinden deneme öncesi, tek grup ön ölçüm-son ölçüm modeli (Karasar, 2007, s. 96) kullanılmıştır. Deneysel bir çalışmada araştırmacı en azından bir bağımsız değişkeni maniple eder ve bunun bir veya daha çok bağımlı 
Türköz, Ü. G. (2020). Bilimin doğası etkinliklerinin ilkokul 4. sınıf öğrencilerinin bilimsel süreç becerilerine etkisi. Journal of Human Sciences, 17(2), 558-571. doi:10.14687/jhs.v17i2.3834

değişken üzerindeki etkilerini belirlemeye çalışır (Altunışık, Coşkun, Bayraktaroğlu ve Yıldırım, 2012, s. 67).

Araştırmada tek grup ön-ölçüm ve son-ölçüm modeli kullanılmıştır. Karasar’a (2007) göre bu modelde amaca bağlı olarak seçilmiş bir gruba bağımsız değişken uygulanır. Çalışma grubundaki öğrencilere Fen Bilimleri dersinde kavramlar kazandırılırken öğrencilerin bilimin doğası anlayışlarını etkileyebileceği düşünülen faktörleri içeren etkinliklerle (problem çözme, tartışma, beyin firtınası vb.) öğrenim yapılmıştır. Çalışma grubundaki bağımlı değişken öğrencilerin bilimsel süreç becerileridir. Nicel olarak ön ölçüm-son ölçüm puanları arasında karşılaştırmalar yapılmıştır.

\subsection{Araştırmanın Çalışma Grubu}

$\mathrm{Bu}$ araştırma ilkokul 4. Sınıf öğrencilerine uygulanan bilimin doğasına yönelik öğretim etkinliklerinin öğrencilerin bilimsel süreç becerilerine etkisini incelemektedir. Çalışmada amaca bağlı örneklem seçimi yöntemine gidilmiştir. Bu tür örneklemede araştırmacı kimlerin seçileceği konusunda kendi yargısını kullanır ve araştırmanın amacına en uygun olanları örnekleme alır (Balcı, 2010, s. 98). Bu çalışmada uygun durum çalışma grubu seçimine gidilmiştir. "Uygun Durum Çalışma Grubu" üzerinde kolayca araştırma yapılacak kişi ve grupların seçilmesidir(Sönmez ve Alacapınar, 2011: 98).

Sönmez (2005)'e göre; deneysel araştırmalarda evren ve örneklem seçimine gidilmemelidir. Bu kapsamda araştırmada evren genellenebilirliği göz ardı edilmiş ve çalışma grubu seçilmiştir. $\mathrm{Bu}$ nedenle Denizli ili merkezinde bulunan orta sosyo-ekonomik düzeydeki ilkokullardan Denizli Ticaret Odası Ahi Sinan ilkokulunda 2012-2013 eğitim-öğretim y1lında öğrenim gören 4. sinıf öğrencileri kapsamında uygulamalar yapılmıştır. Bu okulun seçilme nedeni orta sosyo-ekonomik düzeyde bir okul olmasıyla birlikte bu tarz araştırmalar konusunda öğretmen ve yöneticilerinden gelen taleplerdir.

Çalışma grubu 35’i erkek, 39’u kız öğrenci olmak üzere toplam 74 öğrenciden oluşmuştur. Ancak veri toplama sürecinde öğrencilerin yaptıkları devamsızlık, ön-ölçüm veya son ölçümden herhangi birisine katılamamış olma durumu ve düzgün doldurulmayan formlar nedeniyle; Bilimsel Süreç Becerileri testinde 65 öğrencinin ölçümleri değerlendirmeye alınabilmiştir.

\subsection{Veri Toplama Araci}

Çalışma kapsamında öğrencilerin "Bilimsel Süreç Becerilerini” ölçmek için kullanılan test, Aydoğdu ve Dĭg. (2012) tarafindan ilköğretim 6, 7 ve 8. sinıf öğrencilerine yönelik bilimsel süreç becerilerini ölçmek amacıyla geliştirilmiştir. Ölçek geliştirme sürecinde temel ve üst düzey becerilere yönelik sorular (27 madde), Sivas il merkezinde kolay ulaşılabilir örnekleme yöntemiyle seçilmiş beş ilköğretim okulunda öğrenim gören 6,7 ve 8 . Sınıf $(n=345)$ öğrencilerine uygulanmıştır. 27 maddelik ölçeğin güvenirliği (KR-20) 0.84 bulunmuştur. Alt ve üst \% 27’lik grupların puanları arasındaki ayırt edicilikler incelendiğinde, ölçeğin bütün sorularının istatistiksel olarak anlamlı biçimde $(\mathrm{p}<.05)$ ayırt edici olduğu belirlenmiştir.

Bu testin 4. Sınıf öğrencilerinin bilimsel süreç becerilerini ölçmek amacıyla seçilmesinin temel nedenlerinden birisi alan yazında Fen Bilimleri dersi kapsamında geliştirilmiş ve yayınlanmış en yeni test olmasıdır.

Zorunlu ilköğretimin 5 yıl olduğu dönemlerde, zamana sıkışma pahasına programa alınmış çok sayıda konu ve kavramdan kaynaklandığı düşünülen bu içerik fazlalığı, kimi konu ve kavramlar ilköğretim 6, 7, 8. sınıfa aktarılarak giderilmiştir. Ayrıca, fen konularının gündelik hayata ve teknolojiye yansıyan yönlerine daha çok ağırlık verilerek Fen Bilgisi dersinin adı, Fen Bilimleri olarak değiştirilmiş ve haftada 4 saat olarak okutulması öngörülmüştür (MEB, 2005). 4, 5, 6, 7 ve 8. sinıf Fen Bilimleri dersi ünite organizasyonlarını gösteren kılavuzlar incelendiğinde öğrenme alanları ve ünitelerin aynı olduğu görülmüştür. Fen Bilimleri Dersi Öğretim Programı'nda üniteler oluşturulurken göz önüne alınan temellerden birisinin de sarmallık ilkesi olduğu ve pek çok konuya, giderek derinleşen bir yapıya sahip olarak her sınıfta yer verildiği tespit edilmiştir (MEB, 2005). Bu nedenle "Bilimsel Süreç Becerileri”" ölçeğinin Aydoğdu ve Diğ. (2012)'nin yayınladığı haliyle pilot uygulama için kullanılması uygun görülmüştür. 
Türköz, Ü. G. (2020). Bilimin doğası etkinliklerinin ilkokul 4. sınıf öğrencilerinin bilimsel süreç becerilerine etkisi. Journal of Human Sciences, 17(2), 558-571. doi:10.14687/jhs.v17i2.3834

Bilimsel süreç becerileri ölçeği Raşit Özkardeş İlkokulu'nda öğrenim gören 4. Sınıf ( $n=110)$ öğrencilerine uygulanmıştır. Öğrencilerin sorulara verdikleri yanıtlar "0-yanlış" ve "1-doğru" şeklinde kodlanmış, kodlamalar yapılırken incelenen ölçeklerde isim yazılımış ve cevaplanmadan bırakılmış anketler $(\mathrm{n}=11)$ değerlendirme dışı bırakılmıştır. İstatistiksel işlemlere uygun olan testler $(n=99)$ dikkate alınarak, sorulara verilen doğru ve yanlış cevapların yüzdeleri ve testin güvenirlik $(\alpha=.775)$ hesapları yapılmıştır.

Ölçeğin geçerliğini ve güvenirliğini test etmek amaciyla öncelikle; ortalama, standart sapma, düzeltilmiş madde toplam korelasyonu, düzeltilmiş madde alt ölçek korelasyonu, madde çıkarılınca Alfa değeri, madde düzeyinde iç tutarlılık hesaplanmıştır. Bununla ilgili veriler Tablo 1'deki gibidir.

Tablo 1.Bilimsel Süreç Becerileri Ölçek Maddelerinin Ortalaması, Standart Sapması, Madde-Toplam Korelasyonu

\begin{tabular}{|l|c|c|l|l|c|}
\hline Maddeler & Ortalama & $\begin{array}{l}\text { Standart } \\
\text { Sapma }\end{array}$ & $\begin{array}{l}\text { Düzeltilmiş } \\
\text { Madde } \\
\text { Toplam } \\
\text { Korelasyonu }\end{array}$ & $\begin{array}{l}\text { Madde } \\
\text { cikart1lirsa } \\
\text { Cronbach } \\
\text { Alpha değeri }\end{array}$ & $\begin{array}{l}\text { Madde } \\
\text { düzeyinde iç } \\
\text { tutarl111k } \\
(\boldsymbol{\alpha})\end{array}$ \\
\hline s1 & .37 & .486 & .491 & .758 & \\
s2 & .31 & .466 & .303 & .768 & \\
s3 & .40 & .493 & .327 & .767 & \\
s4 & .48 & .502 & .457 & .759 & \\
s5 & .31 & .466 & .275 & .770 & \\
s6 & .52 & .502 & .173 & .775 & \\
s7 & .30 & .462 & .279 & .769 & \\
s8 & .28 & .453 & .351 & .766 & \\
s9 & .44 & .499 & .273 & .770 & \\
s10 & .51 & .503 & .476 & .758 & \\
s11 & .47 & .502 & .359 & .765 & \\
s12 & .37 & .486 & .112 & .778 & \\
s13 & .70 & .462 & .169 & .775 & \\
s14 & .32 & .470 & .479 & .759 & \\
s15 & .21 & .411 & .095 & .778 & \\
s16 & .41 & .495 & .433 & .761 & \\
s17 & .47 & .502 & .490 & .758 & \\
s18 & .45 & .500 & .455 & .760 & \\
s19 & .39 & .491 & .392 & .763 & \\
s20 & .45 & .500 & .255 & .771 & \\
S21 & .28 & .453 & .351 & .766 & \\
S22 & .18 & .388 & .191 & .773 & \\
S23 & .57 & .498 & .221 & .773 & \\
S24 & .40 & .493 & .095 & .779 & \\
S25 & .37 & .486 & .239 & .772 & \\
S26 & .52 & .502 & .055 & .782 & \\
S27 & .40 & .493 & .177 & .775 & \\
\hline
\end{tabular}

Özgüven'e (1999, s. 97) göre, eğer bir maddenin toplam puanla olan korelasyonu düşük ise, bu, o maddenin ölçekteki diğer maddelerden farklı bir niteliği ölçtüğünü gösterir. Öner'e (1997) göre ise ölçeğin toplanabilirlik özelliğinin bozulmaması için, madde-toplam korelasyonlarının negatif olmaması ve hatta .25 değerinden yüksek olması gerekir, ancak bu da kesin kural değildir. Bir maddenin ölçekten çıkarılabilmesi için, madde silinirse alfa katsayısındaki ve ölçek ortalamasındaki değişime bakmak gerekir. Buna göre, test içindeki 6, 12, 13, 15, 22, 23, 24, 25, 26 ve 27. maddeler 
Türköz, Ü. G. (2020). Bilimin doğası etkinliklerinin ilkokul 4. sınıf öğrencilerinin bilimsel süreç becerilerine etkisi. Journal of Human Sciences, 17(2), 558-571. doi:10.14687/jhs.v17i2.3834

dışında madde toplam (item-total) korelasyonlarının oldukça yeterli düzeyde güçlü ve pozitif olduğu söylenebilir.

27 madde üzerinde yapılan iç tutarlılık güvenirliği analizinde ise ölçeğin Cronbach Alpha $(\alpha)$ değeri .775 olarak bulunmuştur. $6,12,13,15,22,23,24,25,26$ ve 27 Numaralı maddelerin testten çıkarılması ile 17 madde üzerinde hesaplanan Cronbach Alpha $(\alpha)$ değeri .790 olarak tespit edilmiştir. Bununla ilgili veriler Tablo 2. de verilmiştir.

Tablo 2. Bilimsel Süreç Becerileri Ölçek Maddelerinin Ortalaması, Standart Sapması, Madde-Toplam Korelasyonu

\begin{tabular}{|l|l|l|l|l|l|}
\hline Maddeler & Ortalama & $\begin{array}{l}\text { Standart } \\
\text { Sapma }\end{array}$ & $\begin{array}{l}\text { Düzeltilmiş } \\
\text { Madde } \\
\text { Toplam } \\
\text { Korelasyonu }\end{array}$ & $\begin{array}{l}\text { Madde } \\
\text { çlkart1lirsa } \\
\text { Cronbach } \\
\text { Alpha değeri }\end{array}$ & $\begin{array}{l}\text { Madde } \\
\text { düzeyinde id } \\
\text { tutarlilik } \\
(\alpha)\end{array}$ \\
\hline s1 & .37 & .486 & .495 & .771 & \\
s2 & .31 & .466 & .319 & .784 & \\
s3 & .40 & .493 & .349 & .782 & \\
s4 & .48 & .502 & .484 & .772 & \\
s5 & .31 & .466 & .283 & .786 & \\
s7 & .30 & .462 & .232 & .790 & \\
s8 & .28 & .453 & .387 & .779 & \\
s9 & .44 & .499 & .236 & .790 & \\
s10 & .51 & .503 & .511 & .770 & .790 \\
s11 & .47 & .502 & .344 & .782 & \\
s14 & .32 & .470 & .518 & .770 & \\
s16 & .41 & .495 & .400 & .778 & \\
s17 & .47 & .502 & .471 & .773 & \\
s18 & .45 & .500 & .458 & .774 & \\
s19 & .39 & .491 & .338 & .783 & \\
s20 & .45 & .500 & .398 & .793 & \\
S21 & .453 & & & & \\
\hline
\end{tabular}

\subsection{Deneysel işlemler}

İlkokul 4. Sınıf Fen Bilimleri dersi eğitim programı 2012-2013 bahar döneminde bulunan ilk ünite "Geçmişten Günümüze Aydınlatma ve Ses Teknolojileri” ünitesidir. Çalışma grubunda bu ünite doğrultusunda dersler kendi öğretmenleri tarafından işlenmiş ayrıca aşağıda belirtilen etkinlikler de araştırmacı tarafindan işbirlikli öğrenme yaklaşımı çerçevesinde uygulanmıştır. İşbirliğine dayalı öğrenmenin en önemli özelliği öğrencilerin ortak bir amaç doğrultusunda küçük gruplar halinde birbirinin öğrenmesine yardım ederek çalşmadır (Büyükkaragöz ve Çivi, 1996, s. 132). Uygulanan etkinliklerin birçoğunda ve etkinliklerden sonraki raporlaştırma sürecinde öğrenciler, sınıf içinde belirli bir özelliğe göre ayrım yapılmadan belirlenmiş gruplar içinde raporlarını hazırlamışlardır.

\section{Birinci Hafta}

1. Etkinlik: Kapalı Kutu :Bilimsel bilginin, deney ve gözlem sonucu elde edilen verilere dayalı ve zaman içinde değişebilir olduğu; gözlem ve çıkarım arasındaki fark hissettirilmeye çalışıldı (Lederman ve Abd-El-Khalick, 1998).

\section{Ikinci Hafta}

2. Etkinlik: Bilim İnsanı Resmi: Bilim insanı kime denir? Nerede çalışır? Konuları üzerinde öğrencilerin düşünmeleri sağlanarak, bilimsel bilginin öznel olma özelliği işlendi (Lederman ve AbdEl-Khalick, 1998). 
Türköz, Ü. G. (2020). Bilimin doğası etkinliklerinin ilkokul 4. sınıf öğrencilerinin bilimsel süreç becerilerine etkisi. Journal of Human Sciences, 17(2), 558-571. doi:10.14687/ihs.v17i2.3834

\section{Üçüncü Hafta}

3. Etkinlik: Olayları Sıralama: Bilimin hayalci ve yaratıcı doğası ve öznel olma özelliği üzerine çalışmalar yapıldı (Lederman ve Abd-El-Khalick, 1998).

\section{Dördüncü Hafta}

4. Etkinlik: Bilimsel mi? Değil mi?: Bilimsel bilginin özellikleri ve bilimin sosyal ve kültürel yapısı Beşinci Hafta öğrencilere hissettirilmeye çalısıldı (Lederman ve Abd-El-Khalick, 1998).

5. Etkinlik: Genç-Yaşlı: Bilimsel bilginin öznel olma özelliği vurgulanmaya çalışıldı. Bilim insanının bakış açısının, yaptığı gözlemin ve elde ettiği verileri nasıl yorumladığının araştırmaları nasıl etkilediği üzerinde duruldu (Lederman ve Abd-El-Khalick, 1998).

\section{Altinci Hafta}

6. Etkinlik: Paleontolog: Bilimsel bilginin kesin olmayan doğası ve hayalci ve yaratıcı doğası öğrencilere hissettirilmeye çalışıldı (Lederman ve Abd-El-Khalick, 1998).

\section{Yedinci Hafta}

7. Etkinlik: Küçük Bilim İnsanları: Öğrencilere "Küçük Bilim İnsanları" çizgi filmi izletildi. Öğrencilerin bilim, bilim insanı ve bilim insanının nasıl çalıştığı konusunda düşünmeleri sağlandı.

\section{Sekizinci Hafta}

8. Etkinlik: Kara Kutu: Çıkarım ile gözlem arasındaki fark vurgulanmaya çalışıldı (Lederman ve Abd-El-Khalick, 1998).

\section{Dokuzuncu Hafta}

9. Etkinlik: Ayak İzleri: Bilimsel bilginin hayalci ve yaratıcı doğası ve öznel olma özelliği yanında gözlem ve çıkarım arasındaki farklar da öğrencilere hissettirilmeye çalışıldı (Lederman ve Abd-ElKhalick, 1998).

\subsection{Verilerin Analizi}

Verilerin analizinde SPSS 21.0 veri işleme paket programı kullanılmıştır. Bilimsel süreç becerileri (BSB) testi " $0=$ yanlış" " $1=$ doğru“ şeklinde ayrı ayrı kodlanarak, her öğrencinin ön-ölçüm ve son-ölçüm verileri birbirine eşitlenerek SPSS paket programına verilerin girişi yapılmıştır.

Bulguların yorumlamasında kullanılan istatistiksel teknikler aşağıdaki gibidir: Bilimsel Süreç becerileri testine ilişkin verilerin normal dağılım gösterip göstermediği Kolmogorov-Smirnov testi ile kontrol edilmiş, dağılımların normal olduğu belirlendikten sonra ön-ölçüm ve son-ölçüm puanları arasında anlamlı bir fark olup olmadığının belirlenmesi için ise " $\mathrm{t}$ " testi kullanılmıştır. Anlamlılık düzeyi .05 olarak belirlenmiştir.

\section{Bulgular}

Araştırmanın alt problemi; "Bilimin doğası etkinliklerinin öğrencilerin bilimsel süreç becerilerine etkisi nedir?” şeklinde tanımlanmıştır. Bu alt problemi sinamak üzere yapılan $\mathrm{t}$ testi analizleri sonuçları, ilgili verilerle birlikte aşağıda sunulmaktadır.

Tablo 3: Çalı̧ıma Grubuna Ait Bilimsel Süreç Becerileri Testi Ölçümlerine Göre t Ölçümü Sonuçlart

\begin{tabular}{|l|l|l|l|l|l|}
\hline & $\mathbf{N}$ & $\overline{\boldsymbol{X}}$ & $\mathbf{S S}$ & $\mathbf{t}$ & $\mathbf{p}$ \\
\hline Ön ölçüm & 65 & 6,85 & 1,851 & \multirow{2}{*}{$-2,97$} & $0,004^{*}$ \\
Son ölçüm & 65 & 7,75 & 2,158 & & \\
\hline${ }^{*} p<0,05$ &
\end{tabular}

Tabloda görüldüğü gibi çalş̧ma grubundaki öğrencilerin deneysel işlem sonrası kavramsal anlama testi ön ölçüm-son ölçüm puanlarının ortalamalarının önemli bir farklılık gösterip göstermediğini sinamak üzere yapılan eş örneklemli (paired samples) t testi analizi .05 düzeyinde önemli bir farklılık göstermektedir $[\mathrm{t}=-2,97 \mathrm{p}<0,05]$. Bir başka ifadeyle, deneysel işlem sonrasında 
Türköz, Ü. G. (2020). Bilimin doğası etkinliklerinin ilkokul 4. sınıf öğrencilerinin bilimsel süreç becerilerine etkisi. Journal of Human Sciences, 17(2), 558-571. doi:10.14687/jhs.v17i2.3834

çalışma grubunun bilimsel süreç becerileri açısından son ölçüm yönünde anlamlı bir fark oluşmuştur.

\section{Tartışma ve Öneriler}

Araştırmanın alt problemi; "Bilimin doğası etkinliklerinin öğrencilerin bilimsel süreç becerilerine etkisi nedir?” şeklinde tanımlanmıştır. Bu çalışmada bilimin doğasına yönelik etkinliklerle öğrenim gören çalışma grubu öğrencilerinin bilimsel süreç becerileri ölçeği sonölçümden aldıkları puanların ortalaması, ön-ölçümde aldıkları puanların ortalamasından yüksek çıkmıştır. Bilimsel süreç becerilerinden bilim insanları, öğretmenler ve öğrenciler için fen öğrenirken kullanılan bir dizi düşünme becerisi olarak da bahsedilmektedir. Bilim öğrenirken ve öğretirken bilimsel süreç becerileri bir öğretme yaklaşımı olarak kullanılır. Bilimsel süreç becerileri bilgi edinme ve sonrasında elde edilmiş zihinsel ve psikomotor becerilerin kullanımını artıran davranışlardır (Turiman, Omar, Daud, Osman, 2011, s. 114-115). Bilimsel süreç becerileri fen bilimlerinde öğrenmeyi kolaylaştıran, araştırma yol ve yöntemlerini kazandıran, öğrencilerin öğrenmede aktif olmasinı sağlayan, kendi öğrenmelerinde sorumluluk alma duygusunu geliştiren ve öğrenmenin kalıcılı̆̆ını artıran temel beceriler olarak tanımlamaktadır (Çepni ve diğerleri, 1996). Temel süreç becerileri çocukların duyularını aktif olarak kullanmaları ile başlar ve bu süreçte çocuklar deneme yanılma ile öğrenirler, bilgiyi keşfederler ve oluştururlar, problemleri tanımlar ve üzerine düşünürler. Bu sayede çeşitli bilgi ve becerileri kazanan çocuklar problem çözme ve karar verme süreçlerinde aktif olarak rol alabilirler (Martin, Sexton, Franklin ve Gerlovich, 2005: s. 18; Rapudi, 2004: s. 20). Günümüzün karmaşık toplumu, bireylerin konuların bilgi zeminini genişleterek analiz etmesini gerektirir (Cuevas ve diğerleri, 2005, s. 337). Bu amaca ulaşabilmek için ise bireylere bilgiye ulaşma, bilgiyi tanımlama, analiz etme ve yorumlama yolları kazandırılmalıdır. İlköğretimin ilk kademelerinde öğrencilerin bilimsel araştırma geliştirmelerini ve bunları uygulamalarını beklemek yerine bilimsel süreç becerilerinin nasıl kullanılacağını öğrenmeleri gereklidir. Kandır, Yaşar ve Tuncer (2011: s. 28)'e göre bilimsel süreç becerileri öğrenme süreci içinde aktif ve bilinçli şekilde kullanılarak kazanılabilecektir. Bunun yanında Kandır ve diğerleri (2011), çocukların süreç becerilerini kazanabilmeleri için onların yaşına ve gelişim özelliklerine uygun yöntem, teknik ve stratejilerinin etkili şekilde kullanılmasının önemli olduğunu da eklemişlerdir. Benzer şekilde Bağc1Kılıç (2003) öğrencilerin bilimsel süreç becerilerinin ancak kullandıkça gelişeceğini, fakat öğrencilerin yaşlarının da dikkate alınması gerektiğini belirtmiştir.

Bu çalışmada da öğrenciler öğretim programı boyunca gerçekleştirilen tüm sınıf içi ve sınıf dışı etkinliklere aktif şekilde katılmışlar ve bilimsel süreç becerilerini geliştirebilecek pek çok deneyim elde etmişlerdir. Ayrıca öğrencilerin katıldıkları kapalı kutu, kara kutu, ayak izleri, bilimsel mi değil mi?, genç-yaşlı etkinliklerinin bu becerileri kazanmalarını destekleyici nitelikte olduğu görülmüştür. Örnek olarak, "kara kutu” ve "kapalı kutu” etkinliklerinde öğrenciler gözlem; "Ayak izleri”" ve "Bilimsel mi değil mi?" etkinliklerinde sınıflandırma yapma fırsatı elde etmişlerdir. Ayrıca, uygulayıcı tarafindan çocukların bu becerilerini sergilemelerine yönelik sorular ve yönergeler kullanılmıştır. İstatistiksel anlamda öğrencilerin ön-ölçüm-son-ölçüm puanları arasında bulunan fark, öğrencilerin eğitim programı sonrasında bilişsel düzeylerinin arttı̆̆ını ve bunun sonucu olarak bilimsel süreç becerileri puanlarının yükseldiğini göstermektedir. Benzer şekilde Can ve Pekmez (2010) bilimin doğası etkinliklerinin ilköğretim yedinci sınıf öğrencilerinin bilimsel süreç becerilerinin geliştirilmesindeki etkisini araştırdıkları çalısmalarında, ön ölçüm-son ölçüm kontrol gruplu deneme modeli kullanmış ve araştırma sonucunda, bilimin doğası etkinliklerinin bilimsel süreç becerilerini kullanabilme düzeylerini arttırdığı saptamışlardır. Gültekin (2009) ise, araştırmasında; fen eğitiminde proje tabanlı öğrenme uygulamalarının 6. sınıf öğrencilerinin bilimin doğasıyla ilgili görüşlerine, bilimsel süreç becerilerine, kavram gelişimine, başarı ve tutumlarına karş1 etkisi olup olmadığını incelenmiştir. Deneme modellerinden ön ölçüm-son ölçüm kontrol gruplu model kullanılarak yapılmış olan çalışmanın sonucunda proje tabanlı öğrenme uygulamalarının deney grubu içinde öğrencilerde bilimsel süreç becerilerini geliştirdiği gözlemlenmiştir. 
Türköz, Ü. G. (2020). Bilimin doğası etkinliklerinin ilkokul 4. sınıf öğrencilerinin bilimsel süreç becerilerine etkisi. Journal of Human Sciences, 17(2), 558-571. doi:10.14687/jhs.v17i2.3834

Wu ve Hsieh (2006), 6. sınıf öğrencileri ile yaptıkları çalışmada araştırmaya dayalı öğrenme etkinliklerinin araştırma becerileri üzerine etkisini incelemişlerdir. Çalışma sonucunda, tüm öğrencilerin etkinliklerin uygulanmasından sonra araştırma becerilerinin kayda değer şekilde geliştiğini ve öğrencilerin araştırma beceri gelişiminin de birbirini etkilediğini göstermiştir. Şimşek ve Kabapınar (2010), 5. sınıf öğrencilerinin bilime karşı tutumlarında kavramsal anlama ve bilimsel süreç becerileri üzerinde sekiz haftalık sorgulama temelli öğrenme ortamı uygulamalarının etkisini araştırdıkları çalışmalarında sonucun olumlu olduğunu gözlemlemiştir.

Cuevas ve diğerleri (2005) farklı kültürlere sahip 3. ve 4. sınıf öğrencileri için demografik özellikleri ve bilimsel araştırma beceri gelişimleri arasındaki ilişkiyi araştırmaya dayalı eğitim uygulamalarıyla yaptıkları çalısmada incelemişlerdir. Araştırma sonucunda, tüm öğrencilerin araştırma becerilerinin her grupta arttığını ve araştırmaya dayalı eğitim uygulamalarına sınıf, başarı, cinsiyet, etnik köken, sosyoekonomik düzey gibi bağımsız değişkenlerin etkisinin olmadığını saptamışlardır. Yapılan diğer araştırmalara bakıldığında bu araştırma bulgusunun alan yazında yer alan benzer araştırmaların bulguları ile paralellik taşılığı söylenebilir.

İlkokullarda görev yapan öğretmenlerin bilimsel süreç becerileri ve öğretimi konularındaki eksikliklerinin ilgili kurumlar tarafından hazırlanan hizmet içi eğitimlerle giderilmesine yönelik çalışmalara etkin katılımının sağlanmasının bu alana katkı sağlayacağı düşünülmektedir. Buradan hareketle sınıf öğretmenlerinin bilimsel süreç becerilerini geliştirmeye yönelik yapılacak çalışmaların da hem alan yazın hem de okullarda eğitimin niteliğinin artırılması açısından faydalı olacağı düşünülmektedir.

\section{Kaynakça}

Abd-El-Khalick, F. (2012). Teaching with and the nature of science, and science teacher knowledge domains. Science \& Education, DoI. 10.1007/s11191-012-9520-2.

Abd-El-Khalick, F., Bell, R. ve Lederman, N. G. (1998). The nature of science and instructional practice: Making the unnatural natural. Science Education, 82(4), 417- 436.

Akerson, V. L., Abd-El-Khalick, F. S. (2003). Teaching elements of the nature of science: a yearlong case study of a fourth-grade teacher. Journal of Research in Science Teaching, 40, 1025- 1049.

Akerson, V.L. ve Abd-El-Khalick,F. (2005). How should I know what scientists do?- I am just a kid : Fourth-grade students' conceptions of nature of science. Journal of Elementary Science Education, 17(1), $1-11$.

Akerson, V., ve Donnelly, L. A. (2010). Teaching nature of science to K-2 students: What understandings can they attain?. International Journal of Science Education, 32(1), 97-124.

Akerson, V. L., \& Hanuscin, D. L. (2007). Teaching nature of science through inquiry: Results of a 3-year professional development program. Journal of Research in Science Teaching, 44(5), 653-680.

Akerson, V., Nargund-Joshi, V., Weiland, I., Pongsanon, K., \& Avsar, B. (2014). What third-grade students of differing ability levels learn about nature of science after a year of instruction. International Journal of Science Education, 36(2), 244-276.

Altındağ, C., Şahin, C. T., \& Saka, Y. (2012). Bilimin doğası öğretimine yönelik etkinlik örneği. Araşttrma Temelli Etkinlik Dergisi (ATED), 2(1), 1-9.

American Association for the Advancement of Science [AAAS]. (1993). Benchmarks for science literacy: A Project 2061 report. New York: Oxford University Pres.

Arslan, A. (1995). İlkokul ögrencilerinde gözlenen bilimsel beceriler. Yayımlanmamış Doktora Tezi. Hacettepe Üniversitesi Sosyal Bilimler Enstitüsü. Ankara.

Aydoğdu, B. (2006). İlköğretim fen ve teknoloji dersinde bilimsel süreç becerilerini etkileyen değgşkenlerin belirlenmesi. Dokuz Eylül Üniversitesi Eğitim Bilimleri Enstitüsü. Yayımlanmamış Yüksek Lisans Tezi.

Aydoğdu, B. (2009). Fen ve teknoloji dersinde kullanlan farkh deney tekniklerinin ögrrencilerin bilimsel süreş becerilerine, bilimin doğasma yönelike görïslerine, laboratuvara yönelike tutumlarna ve ögrenme yaklassımlarna etkileri. Dokuz Eylül Üniversitesi Eğitim Bilimleri Enstitüsü. Yayımlanmamış Doktora Tezi.

Aydoğdu, B., Tatar, N., Yıldız, E., Buldur, S. (2012). İlköğretim öğrencilerine yönelik bilimsel süreç becerileri ölçeğinin geliştirilmesi. Kuramsal Eğitim Bilim Dergisi 5(3),292-311.

Balc1 A. (2010). Sosyal bilimlerde araștırma yöntem, teknik ve ilkeler, Pegem Akademi, Ankara. 
Türköz, Ü. G. (2020). Bilimin doğası etkinliklerinin ilkokul 4. sınıf öğrencilerinin bilimsel süreç becerilerine etkisi. Journal of Human Sciences, 17(2), 558-571. doi:10.14687/jhs.v17i2.3834

Bağc1-Kilıç, G. (2006). Yeni yaklaşımlar ısı̆ğında ilköğretim bilim ögretimi, Morpa yayıncilık, Yaylacık Matbas1, İstanbul.

Baştürk, R. (2010). Bütün yönleriyle spss ömekli nonparametrik istatistiksel yöntemler, Anı Yayıncllı. Ankara.

Bat, K. (2013). Fen eğitiminde bilimsel yöntem süreci öğretimi üzerine bir inceleme: Pozitivizmden anarşist bilgi kuramına, Pamukkale Üniversitesi Ë̆itim Fakültesi Dergisi, Say1 34 (Temmuz 2013/II), ss. 211-226.

Bell, R. L., Lederman, N. G. ve Abd-El-Khalick, F. (1998). Implicit versus explicit nature of science instruction: an explicit response to palmaquist ve finley. Journal of Research in Science Teaching, 35, 10571061.

Büyüköztürk, Ş. (2002). Sosyal bilimlerde veri analiri ders kitabı. Ankara:Pegem A yayıncllk.

Büyüktaşkapu, S. (2010). 6 yas çocuklarnm bilimsel süreş becerilerini gelistirmeye yönelike yapılandırmac yaklaşma dayal bir bilim ögretim programı önerisi. Selçuk Üniversitesi Sosyal Bilimler Enstitüsü. Yayımlanmamış Doktora Tezi.

Büyüktaşkapu, S., Çeliköz, N., Akman, B.,(2012). Yapılandırmacı bilim eğitimi programı'nın 6 yaş çocuklarının bilimsel süreç becerilerine etkisi. Eğitim ve Bilim. Cilt 37, Sayı 165.

Can, B., ve Pekmez, E. Ş. (2010). Bilimin doğası etkinliklerinin ilköğretim yedinci sınıf öğrencilerinin bilimsel süreç becerilerinin geliştirilmesindeki etkisi. Pamukkale Üniversitesi Eğitim Fakültesi Dergisi, 27(27), 113123.

Can B. (2008). İlkögretim öğrencilerinin bilimin doğass ile ilgili anlayışlarn etkileyen faktörler. dokuz eylül üniversitesi eğitim bilimleri enstitüsï. Yayımlanmamıș Doktora Tezi.

Cartier, J., Rudolph, J., \& Stewart, J. (2001). The nature and structure of scientific models. National Center for Improving Student Learning and Achievement in Mathematics and Science.

Cevizci, A. (2013). Felsefe sö̋liigüü.11. Basım. Paradigma Yayınları. İstanbul.

Clough, P. M., Olson, K.J., Madson,J. A. Ve Taylor, J. M. (2005). No matter where you go, there you are: the primacy of the nature of science in scientific literacy. NARST Mission Statement, http:// www.educ.sfu.ca / narstsite / conference

Creswell, J.W. (2014) Nitel, nicel ve karma yöntem yaklaşımlar: araştrma deseni (research design). Ed: Selçuk beşir Demir. Eğiten Kitap. Ankara.

Cuevas, P., Lee, O., Hart, J. and Deaktor, R. (2005). Improving science inquiry with elementary students of diverse backgrounds. Journal of Research in Science Teaching, 42(3), 337-357.

Çelikdemir, M. (2006). İlkëgrretim ögrencilerinin bilimin doğasm anlama düreylerinin arasstrnlması. Yayınlanmamış Yüksek Lisans Tezi, İlköğretim Fen ve Matematik Alanları Eğitimi Bölümü ODTÜ.

Çepni, S., Ayas, A., Johnson, D. Ve Turgut, M. F. (1996). Fiz̨ik ögretimi. Ankara: Milli Eğitimi Geliştirme Projesi Hizmet Öncesi Öğretmen Eğitimi Deneme Basımı.

Çil, E., (2010). Bilimin doğasmmn kavramsal değģsim pedagojisi ve doğrudan yansitıc yaklașım ile ögretilmesi: Işık ünitesi örneği. Yayınlanmamış Doktora Tezi, Fen Bilimleri Enstitüsü Karadeniz Teknik Üniversitesi.

Çilingir, L. (2013). Bilimin doğasi ve bilimsel süreş becerileri, içinde. M. Demirbaş (Ed.). Bilimin doğasi ve öğretimi (2-21). Pegem Akademi. Ankara.

Çokadar, H., \& Demirtel, Ş. (2012). Doğrudan yansıtıcı etkinliklerle öğretimin öğrencilerin bilimin doğası anlayışlarına ve fene yönelik tutumlanna etkisi. Pamukkale Üniversitesi Ë̆itim Fakültesi Dergisi,31(31), 67-79.

Doğan, N., Çakıroğlu, J., Çavuş, S., Bilican, K., ve Arslan, O. (2011). Öğretmenlerin bilimin doğası hakkındaki görüşlerinin geliştirilmesi: Hizmetiçi eğitim programının etkisi. Hacettepe Üniversitesi Eğitim Fakültesi Denisi, 40(40).

Doğan, N., Çakıroğlu, J., Çavuş, S., Bilican, K., ve Arslan, O. (2012). Bilimin Doğası ve Öğretimi. Ankara: Pegem Akademi.

Driver, R. (1995). Constructivist Approaches to Science Teaching içinde Steffe, L., P., Gale, J. Constructivism In Education. Lawrance Erlbaum Associates, Inc.

Driver, R., Leach, J., Millar, R., \& Scott, P. (1996). Young people's images of science. McGraw-Hill International.

Duggan, S., \& Gott, R. (1995). The place of investigations in practical work in the UK national curriculum for science. International Journal of Science Education, 17(2), 137-147.

Duit, R.\& Treagust, D. F. (2003) Conceptual change: A powerful framework for improving science teaching and leaming, International Journal of Science Education, 25:6, 671-688, DOI: 10.1080/09500690305016

Ekiz, D. (2009). Ë̈itimde araştrma yöntem ve metotlarna giriş. Ankara: Anı Yayıncilik.

Erduran, S.(2014). Beyond nature of science: The case for reconceptualising 'science' for science education. Science Education International, 25 (1), 933-111 
Türköz, Ü. G. (2020). Bilimin doğası etkinliklerinin ilkokul 4. sınıf öğrencilerinin bilimsel süreç becerilerine etkisi. Journal of Human Sciences, 17(2), 558-571. doi:10.14687/jhs.v17i2.3834

Ergin, Ö., Şahin-Pekmez, E. \& Öngel-Erdal, S. (2005). Kuramdan uygulamaya deney yoluyla fen ögretimi. 1. Bask1, Dinazor Kitabevi, Kanylmaz Matbaas1, İzmir.

Fraenkel, J.R. ve Wallen, N.E. (2009). How to design and evaluate research in education. 7. Bask1, McGraw Hill Higher Education, New York.

Gott, R. and Mashiter, J. (1991) Practical work in science - a task-based approach? In practical science. Woolnough, B.E. (ed). (Buckingham, Open University Press).

Guilherme, E., Faria, C., \& Boaventura, D. (2015). Exploring marine ecosystems with elementary school Portuguese children: inquiry-based project activities focused on 'real-life'contexts. Education 3-13, (ahead-of-print), 1-12.

Gültekin, Z., (2009). Fen eğitiminde proje tabanli ögrenme uygulamalarinin ögrencilerin bilimin doğasiyla ilgili görï̈lerine, bilimsel süreç becerilerine ve tutumlarina etkisi. Yayınlanmamış Yüksek Lisans Tezi. Marmara Üniversitesi Eğitim Bilimleri Enstitüsü. İstanbul.

Harlen, W. (1999). Purposes and procedures for assessing science process skills. Assessment in Education, Vol. 6, No. 1.

Harlen, W. (2004). Evaluating inquiry-based science developments. In a paper commissioned by the National Research Council in preparation for a meeting on the status of evaluation of Inquiry-Based Science Education (Vol. 11). from http://www.nsrconline.org/pdf/NAS paper eval inquiry science.pdf. Son erişim tarihi: 30.03.2015

Irz1k, G., \& Nola, R., (2011). A family resemblance approach to the nature of science for science education, Science \& Education, 20:591-607.

Kabapınar, F. (2003). Kavram yanılgılanının ölçülmesinde kullanılabilecek bir ölçeğin bilgi-kavrama düzeyini ölçmeyi amaçlayan ölçekten farklılıkları, Kuram ve Uygulamada Eğitim Yönetimi, sayı 35, 398-417

Kandır, A., Yaşar, M.C. ve Tuncer, N. (2011). Okul öncesi dönemde fen eğitimi. İstanbul: Morpa Kültür Yayınları.

Karasar N. (2007). Bilimsel araştırma yöntemi, Nobel Yayın Dağıtım, Ankara.

Kaya, O. N., Doğan, A., \& Öcal, E. (2008). Turkish elementary school students' images of scientists. Eurasian Journal of Educational Research, 32, 83-100.

Khishfe, R. (2014). Explicit nature of science and argumentation instruction in the context of socioscientific 1ssues: An effect on student learning and transfer. International Journal of Science Education, 36(6), 9741016.

Khishfe, R. ve Abd-El-Khalick, F. (2002). Influence of explicit and reflective versus 1mplicit 1nquiry-oriented instruction on sixth graders' views of nature of science, Journal of Research in Science Teaching, 39, 7 551578.

Khishfe, R. ve Lederman, N. (2006). Teaching nature of science within a controversial topic: 1ntegrated versus nonintegrated, Journal of Research in Science Teaching, 43, 4, 395-418.

Korkmaz, H., \& Kavak, G. (2010). İlköğretim öğrencilerinin bilime ve bilim insanına yönelik imajları.Illkögretim Online,9(3).

Köseoğlu, F., Tümay, H., ve Budak, E. (2008). Bilimin doğası hakkında paradigma değişimleri ve öğretimi ile ilgili yeni anlayışlar. Gari Eğitim Fakültesi Dergisi, 28(2).

Kuhn, T. S. (1962). The structure of scientific revolutions. Chicago: University of Chicago Press.

Küçük ,M. (2006). Bilimin doğasın ilkögrretim 7. sinı ögrrencilerine ögretmeye yönelik bir çalışma, Karadeniz Teknik Üniversitesi, Yayımlanmamış Doktora Tezi, Trabzon.

Lederman, N. G.: 1992b, 'Students' and teachers' conceptions of the nature of science: do they really influence teacher behavior?', Science Education, 71, 721-734.

Lederman, N.G. (1999). Teachers' understanding of the nature of science and classroom practice: factors that facilitate or impede the relationship, Journal of Research in Science Teaching, 36, 8 916-929.

Lederman, N. G. ve Abd-El-Khalick, F. (1998). Avoiding de-natured science: activities that promote understanding of the nature of science. In W. Mccomas (Ed.), The nature of science in science education: rationales and strategies, (Pp.83-126), Dordrecht, The Netherlands: Kluwer Academic Publishers.

Lederman, N.G., Abd-El-Khalick, F., Bell, R.L. ve Schwartz, R.S. (2002). Views of nature of science questionnaire (vnos): toward valid and meaningful assessment of learners' conceptions of nature of science, Journal of Research in Science Teaching, 39 497-521.

Lederman, J.S., \& Khisfe, R. (2002). Views of the nature of science, Form D. Unpublished paper, Illinois Institute of Technology, Chicago, IL. 
Türköz, Ü. G. (2020). Bilimin doğası etkinliklerinin ilkokul 4. sınıf öğrencilerinin bilimsel süreç becerilerine etkisi. Journal of Human Sciences, 17(2), 558-571. doi:10.14687/jhs.v17i2.3834

Lederman, J. S., Lederman, N. G., Bartos, S. A., Bartels, S. L., Meyer, A. A., \& Schwartz, R. S. (2014). Meaningful assessment of learners' understandings about scientific inquiry-The views about scientific inquiry (VASI) questionnaire. Journal of Research in Science Teaching, 51(1), 65-83.

Lederman, N. G., Wade, P. D. ve Bell, R. L. (1998). Assesing the nature of science: what is the nature of our assessments? Science and Education, 7, 595-615.

Martin, D. J. (1997). Elemantary science methods: a constructivist approach, Delmar Publishers, NY.

Martin, D. J. (2001). Constructing early childhood science. USA: Delmar Thomson Learning.

Martin, R., Sexton, C., Franklin, T., Gerlovich, J. (2005). Teaching science for all children: an inquiry approach (with "Video Explorations" Video Workshop CD-ROM), 4/e. Pearson/Allyn and Bacon.

Mayer, D., Sodian, B., Koerber, S., \& Schwippert, K. (2014). Scientific reasoning in elementary school children: Assessment and relations with cognitive abilities. Learning and Instruction, 29, 43-55.

McComas, W. (1998). The nature of science in science education: rational and strategies. The Netherlands: Kluwer Acedemic Publishers.

McComas, W. F., Clough, M. P. \& Almazroa, H. (1998). The role and character of the nature of science in science education, in W. F. McComas (ed.) The nature of science in science education rationales and strategies, (s:3- 39). London: Kluwer Academic Publishers.

McCormick, R.; Paechter, C. (1999). Learning and knowledge. The Open University: Paul Chapman Publishing.

MEB. (2005), T.C. Millî Eğitim Bakanlı̆ı Talim Ve Terbiye Kurulu Başkanllğı İlköğretim Fen Ve Teknoloji Dersi (4 Ve 5. Sınıflar) Öğretim Programı, Ankara,

MEB (2013) Milli Eğitim Bakanlığı Talim ve Terbiye Kurulu Başkanlığı Fen Bilimleri Dersi Programı.

Mathews, M. R. (2012). Changing the focus: From nature of science (NOS) to features of science (FOS), içinde Myint Swe Khine (ed.) Advences in Nature of Science Research, Springer.

Metin, D. (2009). Yaz bilim kampinda uygulanan yönlendirilmis araștrma ve bilimin doğası etkinliklerinin ilkögretim 6. ve

7. simftaki çocuklarn bilimin doğası bakkendaki düsüncelerine etkisi. Yayınlanmamış yüksek lisans tezi. Abant İzzet Baysal Üniversitesi Sosyal Bilimler Enstitüsü. Bolu.

Miles, B., M. \& Huberman, A., M., (1994). Qualitative data analysis, Sage Publications, USA.

Murphy, C., Murphy, C., ve Kilfeather, P. (2011). Children making sense of science. Research in Science Education, 41(2), 283-298.

Muşlu, G. (2004). İlköğretim ikinci kademe ögrencilerinin bilim ve bilimsel süreş kavramlarna ilişkin algzlar. Marmara Üniversitesi Eğitim Bilimleri Enstitüsü Basılmamış Yüksek Lisans Tezi .

Muşlu, G. (2008). İlkögretim 6. sme ögrencilerinin bilimin doğasm sorgulama dïzeylerinin tespiti ve çesitli etkinliklerle geliştirilmesi. Marmara Üniversitesi Eğitim Bilimleri Enstitüsü Basılmamış Doktora Tezi.

National Research Council. [NRC]. (1996). National science education standards. Washington, DC: National Acedemy Pres.

National Research Council [NRC]. (2000). Inquiry and the national science education standards. Washington, DC: National Academies Press.

Nola, R. (1997). Constructivism in science and science education: A philosophical critique. Science Education, 6, 55-83.

Öner, N. (1997). Türkiye'de kullanulan psikolojik testler: Bir başvuru kaynağg. İstanbul: Boğaziçi Üniversitesi Yayınlan.

Özgüven, İ. E. (1999). Psikolojik testler. Ankara: PDREM Yayınları.

Özmen, H. (2004). Fen öğretiminde öğrenme teorileri ve teknoloji destekli yapılandırmacı öğrenme. The Turkish Online Journal of Educational Technology. 3 (1).

Padilla, M. J. (1990). The science process skills. Research Matters-to the science Teacher, 9004. http://www.educ.sfu.ca/narstsite/publications/research/skill.htm Son Erişim Tarihi: 30.03 .2015

Pekmez, E.Ş. (2000). Procedural understanding: teachers' perceptions of conceptional basis of practical work, Yayınlanmamıs Doktora Tezi, The University of Durham, School Of Education, Durham.

Rapudi, M. A. (2004). The effect of cooperative learning on the development of learners' science process skills. Unpublished Master's Thesis. University of South Africa, South Africa.

Schwartz, R. S. \& Lederman, N. G. (2002). "It's the nature of the beast": The influence of knowledge and intentios on learning and teaching nature of science. Journal of Research in Science Teaching, 39 (3), 205-236.

Schwartz, R. S., Lederman, N.G., \& Crawford, B.A. (2004). Developing views of science in an authentic context: an explicit approach to bridging the gap between nature of science and scientific inquiry. Science Education. 
Türköz, Ü. G. (2020). Bilimin doğası etkinliklerinin ilkokul 4. sınıf öğrencilerinin bilimsel süreç becerilerine etkisi. Journal of Human Sciences, 17(2), 558-571. doi:10.14687/jhs.v17i2.3834

Schwartz, R. S., Westerlund, J. F., García, D. M., Taylor, T. A. (2010). The impact of full immersion scientific research experiences on teachers' views of the nature of science. Electronic Journal of Science Education, Vol. 14, No. 1.

Sönmez, V. (2005). Bilimsel araştırmalarda yapılan yanlışlılar. Ë̈tim Araștrmalar Dergisi. 18. 150-170.

Sönmez, V., Alacapınar, F.G. (2011).Örneklendirilmis Bilimsel Arasstrma Yöntemleri. Ankara: Anı Yayıncilık.

Şimşek, C. L. (2010). Sınıf öğretmeni adaylarının fen ve teknoloji ders kitaplanındaki deneyleri bilimsel süreç becerileri açısından analiz edebilme yeterlilikleri. İlkögretim Online, 9(2).

Şimşek, P. and Kabapınar, F. (2010). The effects of inquiry-based learning on elementary students' conceptual understanding of matter, scientific process skills and science attitudes. Procedia-Social and Behavioral Sciences, 2(2), 1190-1194.

Taşdemir, A. (2013). Bilimin doğasi ve bilimsel süreç becerileri, içinde. M. Demirbaş (Ed.). Bilimin doğasi ve öğretimi (191-228). Pegem Akademi. Ankara.

Tavşancıl, E. (2005). Tutumlarn ölçülmesi ve SPSS ile veri analį̧i. Ankara: Nobel Yayınevi

Turiman, P., Omar, J., Daud, A. M., \& Osman, K. (2012). Fostering the 21 st century skills through scientific literacy and science process skills. Procedia-Social and Behavioral Sciences, 59, 110-116.

Ulu, C. (2011). Fen ögretiminde araştrma sorgulamaya dayah bilim yažma arac kullanmmmn kavramsal anlama, bilimsel süreş ve üstbiliş becerilerine etkisi. Yayınlanmamış doktora tezi, Marmara Universitesi, Eğitim Bilimleri Enstitusu.

Ünal, G. (2009) Modellemeye dayah fen ögretiminin ögrencilerin kavramsal anlama düzeylerine, bilimsel süreş becerilerine, bilimsel bilgi ve varlke anlayzşlarna etkisi: 7. smif ışı ënitesi örneği. Dokuz Eylül Üniversitesi Eğitim Bilimleri Enstitüsü. Yayımlanmamış Doktora Tezi.

Walls, L. (2009). A critical hermeneutic study: Third grade elementary african american students' views of the nature of science. Yayınlanmamış Doktora Tezi. Purdue University.

Wu, H. K. and Hsieh, C. E. (2006). Developing sixth graders' inquiry skills to construct explanations in inquiry based learning environments. International Journal of Science Education, 28(11), 1289-1313.

Yılmaz-Tüzün, Ö., ve Özgelen, S., (2012) Fen bilgisi öğretmen adaylarının bilimsel süreç becerilerini uygulama hakkındaki inançları: bir durum çalışması. Eğitim ve Bilim, Cilt 37, Sayı 164

Yurt, Ö. (2013). 60-72 aylhk çocuklar için bilim ögrrenmeyi değgerlendirme testi'nin geçerlike güvenirlik çalsșmast ve arasstrmaya dayah bilim eğitim programinn bilim ögrenmeye etkisinin incelenmesi. Yayınlanmamış Doktora Tezi. Gazi Üniversitesi Eğitim Bilimleri Enstitüsü. Ankara.

Yücel, M. (2009). Etkileşimli kusa taribsel bikâyelerin kullanmmmn ilkögrretim ikinci kademe ögrencilerinin bilimin doğasma yönelik anlayzşlarm geliştirmesindeki etkililiği. Yayınlanmamış Doktora Tezi. Gazi Üniversitesi Eğitim Bilimleri Enstitüsü. Ankara.

\section{Extended English Summary}

Scientific process skills are the foundations of science and allows doing research and drawing conclusions. Scientific process skills, perhaps one of the most important tools to produce and edit information about people around the world. Children at elementary level use their scientific process skills when creating and researching their own problems in a way similar to the way scientists use in their research. Therefore, the students needed to have the understanding and skills to do scientific researches.

Scientific process skills are examined in two main groups as basic process skills and high level process skills. Basic process skills; While observation, comparison, classification, scientific communication, measurement, estimation and inference are the processes, high level process skills are; determining and controlling variables, constructing and testing hypotheses, designing and conducting experiments, functional definition, interpreting data and modeling. The acquisition of basic process skills takes place in the early years of preschool and elementary education, while the acquisition of high-level process skills takes place in the upper classes of primary education (Yurt, 2013, p. 14).

Elementary School 4th grade Science Course curriculum is the first unit in the spring semester of 2012-2013, "Lighting and Sound Technologies from Past to Present". In the study group, the courses were taught by their own teachers in line with this unit, and the activities were 
implemented by the researcher (such as mysterious footprints, secret box, draw a scientist, scientific or not?, events ranking..) within the framework of a cooperative learning approach. In most of the activities implemented and in the reporting process after the activities, the students prepared their reports in groups determined without discrimination according to a specific feature in the classroom.

The aim of this study is to investigate the effect of nature of science activities on elementary 4th grade students' scientific process skills. The study group of the study is 65 fourth grade students educating in Denizli in a medium socio-economic elementary school in the term of 2012-2013. It is to mention that this study is limited to this group of subjects, but more studies with larger groups can be designed in the future, and therefore other applications for this area of research can be created.

The study was conducted with quantitative research methods. One group pretest-posttest measurement in this study was applied to the experimental model. For data collection; scientific process skills scale was used. One of the main reasons why this test was chosen to measure the scientific process skills of Grade 4 students is that it is the newest test developed and published in the field of Science in the literature. The survey was conducted by scientists during class and lasted 9 weeks and all students were given the scales as pretest and posttest.

The evaluation of the questionnaires was carried out with the statistical program SPSS 21.0. The scale results was coded as " $0=$ false" and " $1=$ right" and all the data was synchronized between pretests and posttests. For the interpretation of the data collected, first of all, all data was examined if their distribution normal or not with Kolmogorov-Smirnov test. After determining the data was normal " $t$-test" used whether there is a significant difference between pre- measurement and post- measurement.

The results showed that there are significant differences between pretest and posttest with respect to science process skills in favor of posttests. The scientific process skills are referred to as a range of thinking skills used for learning science for scientists, teachers and students. In this study, students participated actively in all classroom curriculum and classroom activities and have achieved a lot of experience to improve their scientific process skills. In the first grade of elementary education expect students' applications to learn how to use the scientific process skills are required instead of scientific research and development. The difference between pre- test and post- test scores of students in the statistical sense, the cognitive level of students has increased after the training program and as a result, it shows that the rise of the scientific process skills scores. It can be said that the research findings of this study move in line with the findings of similar researches.

It is thought that the active participation of the teachers working in elementary schools to eliminate their deficiencies in scientific process skills and teaching with in-service trainings prepared by the relevant institutions will contribute to this field. From this point of view, it is thought that the studies to be carried out to improve the scientific process skills of the classroom teachers will be beneficial in terms of increasing the quality of education both in literature and schools. 